\title{
The Inconsistence Of Laws In The Registration Of Land Rights Transfer In Order Of Tax Amnesty
}

\author{
Angelica Saulina Hutapea \\ Program Studi Magister Kenotariatan \\ Fakultas Hukum Universitas Brawijaya \\ Jl. M.T.Haryono No.169, Malang 65145, Indonesia \\ Email: angelicasaulina@gmail.com
}

\begin{abstract}
The writing of this journal discusses legal issues related to legislation inconsistencies concerning registration of land rights transfer which related to tax amnesty. In accordance with Article 37 of Government Regulation No. 24 of 1997 that only recognizes land rights transfer trough trade, exchange, grant, inbreng, and other legal act of rights transfer, but with the existence of Perkaban No. 15/2017, it states that the registration of land rights transfer can be based on the nominee agreement. The objective of this journal is to analyze the implications of legislation inconsistencies concerning registration of land rights transfer which related to tax amnesty and the validity of nominee agreement based on Indonesian law. The research method used is normative juridical with legislation approach and conceptual approach. The discussion result of this journal is the authorization of nominee agreement usage in terms of registration of land rights transfer, but only in the case of tax amnesty, refers to the interpretation of Article 1337 of Civil Code which states that if the things that are prohibited set forth in the law then the thing in question is allowed.
\end{abstract}

Key Words: legislation inconsistency, registration of land rights transfer, tax amnesty

\section{INTRODUCTION}

Land is a valuable asset for the community life for a long time, because of its economic value added time by time. This makes peoples to compete to employ it as future investment. The land regulation mainly regulate in Law Number 5 Year 1960 on the Agrarian Basic Regulation (hereinafter called UUPA). The purposes of UUPA as stated in its General Explanation are: ${ }^{1}$

1. To lay the groundwork in the making of Agrarian National Law, which will be a tool for bringing prosperity, happiness and justice to the State and people, especially the peasants, in the framework of a just and prosperous society;

2. To lay the groundwork to conduct the unity and simplicity of agrarian law

3. To lay the groundwork to give the legal certainty on land rights for all Indonesian people

One of the purposes of UUPA is to give the guarantee of legal certainty on land rights

Urip Santoso.(2010). Pendaftaran dan Peralihan Hak atas Tanah, Jakarta: Kencana, p.1 
for all Indonesian people which realized by conducting complete and clear written law and implemented it consistently with its regulation, and also by perform land registration for the rights holder in order to proof their rights easily, and for other party (buyer or creditor candidate) could get approriate information on land which will be legal actions object. ${ }^{2}$

Land registration hold by the government in all of Indonesia's territory as regulated in Article 19 paragraph 1 UUPA,

"in order to guarantee the legal certainty, the government conducted land registration in entire Indonesia's territory based on laws, regulate with Government Regulation"

Since UUPA entry into force and after the enactment Government Regulation Number 24 Year 1997 on Land Registration (hereinafter called as PP Land Registration), every agreement that intent to transfer land rights, burden the land rights and others legal acts before enlisted should be proven in advance with document made by and in front of the Public Notary (hereinafter called as PPAT) which appointed by the Head of Land Agency (Ps. 37 PP Land Registration). The registration of land rights transfer and removal of land rights is particularly based on Article 37 paragraph (1) PP Land Registration which reads as follow,

"Transition of land rights and the ownership rights of an apartment units through buying and selling, reciprocates, grants, the companies income and other legal acts of removal rights, except the transfer of rights through an auction could only be registered if proofed by document made by the authorized Public Notary according to regulation of applicable legislation".

Referring to Article 1 Sub-Article 1 of the Government Regulation on Land Registration which explains that certificate is the evidence of ownership on land rights and Article 1 paragraph (1) PP Land Registration regarding various transitional rights on land which could only be done through buying and selling, reciprocates, grants, the companies income and other legal acts of removal rights ${ }^{3}$ as evidenced document by the Public Notary, in fact does not rule out the possibility for some people to do legal smuggling in the filed of ownership land by deviating the above rules which is by entering a Nominee Agreement or Name Loan Agreement. Indeed, Nominee Agreement in Indonesia does not violate the regulation laws although it has not been explicitly stipulated that the agreement is allowed.

The Nominee Agreement in fact does not necessarily reflect the law confiction so that it can create a conflict of interest in the field of defense and when looking at the terms of agreement validity which is the objective requirement, does not fulfill legal contents since it was concerning something prohibited. Nevertheless, after the Law of tax amnesty released,

$2 \quad$ Ibid.,p.2. 
explicitly allows the existence of a nominee agreement as defined in Article 15 paragraph (1) of the tax amnesty which reads as follow:

"Taxpayers who have obtained certificate and pay the ransom on: a. immovable property in the form of land; and/or b. property of holdings which has not been reversed on behalf of the taxpayer, should transfer the right to the name of the taxpayer".

Meanwhile, Article 15 Paragraph (2) of the tax amnesty states that tax amnesty on immovable property in the form of land and buildings can be made by the transfer of rights or signing the statement letter by both parties in the presence of a Notary. The statement will state that immovable property in the form of land and building is true of the taxpayer who excuses the tax on the object. It is then reinforced by the Ministerial Regulation of Agrarian Affairs and Spatial / Head of the National Land Agency of the Republic of Indonesia Number 15 Year 2017 concerning the Registration of Land Rights Transfer in the Frame of Tax Amnesty (hereinafter called Perkaban Number 15 Year 2017) obviously instruct the name of the transfer of land rights and mention the word "nominee" explicitly supplemented by Circular Letter Number 9 / SE / X / 2017 concerning the instruction of the implementation on Perkaban Number 15 of 2015. Seeing the problem arises above, there is a non synchronization and inconsistence between the rules which is about the registration of land rights transfer in Article 37 PP Registration on Land with Perkaban Number 15 Year 2017. This can lead to overlapping in regulation of legislation that affects the legal certainty.

Based on the background that has been raised above, the research questions to this research are; what is the implication of inconsistence of legislation in the field of registration of land rights transfer in order of tax amnesty (especially in Perkaban Number 15 Year 2017 with Government Regulation Number 24 Year 1997)? How is the validity of the nominee agreement in the rule of law in Indonesia?

\section{METHOD}

The research method used in this research is normative juridical research, which is research that has been done by reviewing various legal formal rules such as Laws, Regulations and literature containing theoretical concepts which then connected with the problems that will be discuss here. ${ }^{3}$ The legal materials collected further processed through the structuring phase, describe and systematize of legal materials and analyzing as a legal

Peter Mahmud Marzuki.(2008). Penelitian Hukum, Jakarta: Kencana Prenada Media. 
research which is through the legal reasoning stage that is logic, systematic and coherent. ${ }^{4}$

The method of problem approach used in this research is the legislation approach that examines all laws and regulations related to the legal issues being handled and the conceptual approach which is a benchmark approach to the views and doctrines that develop in the study of law.

\section{ANALYSIS AND DISCUSSION}

\section{Implications of Inconsistencies of Legislation in the Field of Registration of Land Rights} Transfer In Order of Tax Amnesty

Every legislation has different purpose and objectives to one another so it often cause the existing regulations not running optimally. The difference lies in the matter of a regulation which essentially governs the same object will create an inconsistence condition of law, as Kusnu Goesniadhie stated it as disharmony of law. ${ }^{5}$ Factors that can lead to potential disharmony of law include the following:

1. Many number of laws and regulations apply in the government system

2. Difference interests and interpreations

3. The gap between technical understanding and legal understanding of good governance

4. Law constraints encountered in the application of legislation, which consists of regulatory mechanisms, anticipation of changes and enforcement

5. Law obstacles faced in the use of legislation

Factors cause the inconsistencies of law in its own practice according to L.M. Gandhi are as follows:

1. Differences between various laws or legislation. The increase number of regulations make it difficult to recognize all the existing rules so that the provision that mentions everyone is considered to know the applicable law is ineffective

2. Disagreement between the law and the implementing regulations

3. Difference between the legislation and policies on the government agencies

4. Difference between legislation and the Jurisprudence also the form letter of the Supreme Court

5. Central government agencies policies are contradictory

6. The difference between central and local government policies

4 Nurbani, Erlies Septiana.(2018). Environmental Protection in International Humanitarian Law, UNRAM Law Review, Volume 2 Issue 1 2018, p.3.

5 Kusnu Goesniadhie.(2010). Harmonisasi Sistem Hukum, Mewujudkan Tata Pemerintahan yang Baik, Malang: A3 dan Nasa Media, p.18 
7. The difference between the authority of government agencies because of the unsystematic and unclear division authority

The conflicting factors arised in this research is between the Government Regulation of Land Registration which is PP Number 24 Year 1997 with the Regulation of the Ministerial Regulation of Agrarian Spatial Number 15 of 2017 on the Registration of Land Rights Transfer in the Frame of Tax Amnesty. Regarding arrangement on the regulation of land rights transfer itself is not regulated in only one legislation, but there are several laws governing these provisions, which are in Article 19 of the Agrarian Basic Law (UUPA), PP Land Registration (PP 24 of 1997) as the implementation of land registration, Regulation of Agrarian Minister/ Head of National Land Agency (Permen Agraria/Kepala BPN) Number 3 Year 1997 on the Implementation of Government Regulation Number 24 of 1997 on Land Registration also Perkaban Number 15 Year 2017 that regulates the registration of land transfers through procedures outside the regulation of PP 24/1997, which is the transfer of registration of land rights by way of nominee agreement, which may occur in the frame of tax amnesty.

Arrangement for registration of land rights transfer since the establishment of Tax Amnesty which regulates the registration of land rights that lead to the inconsistencies of law. Inconsistencies of Law itself overcome by harmonizing related regulation and conforming various interests, adjusting to higher legal norms, equal, lower, non-legal norms, and seeking to streamlined a concept of legislation or the law which has existed.

It is known that there are two rules governing the registration of land rights transfer, it is necessary to compare the processes and provisions on the registration and land transfer in the frame of tax amnesty. This comparative effort conducted is aim of find differences in the treatment of the general process of land transfer with land transfer in the frame of tax amnesty.

Starting from the general process of land transfers, the transitional forms of land rights are classified by switching and diverting. Switching is simply because the owner of land right dies, in other words switching with the only way is through inheritance. Switching also commonly reffered as transition due to law events. While diverting is often referred as a transition due to legal action since the transfer of rights to one's land to another party caused by legal actions deliberately made by both parties. ${ }^{6}$ Such legal act may take the form of buying and selling, reciprocates, investing in capital or grant by the Public Notary.

$6 \quad$ Ibid., p.301. 
Legal basis of the Public Notary in the field of making an authentic deed for the transfer of land rights caused by a legal act is Government Regulation Number 24 year 2016 concerning Regulation and Position of the Public Notary (hereinafter referred to as PP PPAT). It has become the main duty and authority of the PPAT to make certificate as a valid evidence of certain legal actions concerning land rights or ownership rights in units of flats which are stated in Article 2 paragraph (1) PP PPAT. Whereas in Article 2 paragraph (2) PP PPAT, affirms that legal actions that are within the scope of PPAT's authority are buying and selling, reciprocates, grants, the company income (inbreng), shared rights, granting of building rights or land use rights of the ownership rights, granting of mortgage rights and authorization to impose mortgage rights.

Furthermore, namely the process of transferring land in the context of tax amnesty. Registration and transfer of land in the context of tax amnesty is based on the Regulation of the Minister of Agrarian and Spatial Planning/ Head of National Land Agency Republic Indonesia Number 15 Year 2017 concerning Registration of Transition of Land Rights in the Framework of Tax Amnesty (hereinafter referred to as Perkaban Number 15 of 2017). Perkaban Number 15 Year 2017 applies from August 14, 2017. Shortly after Perkaban released, born the guidelines of implementation which is the Circular of the Minister of Agrarian and Spatial Planning/ Head of the National Land Agency of Republic Indonesia Number 15 Year 2017 concerning Registration of Transition of Land Rights in the frame of Tax Amnesty (hereinafter referred to as SE No. 9/SE/X/2017). The Circular was ratified on October 10, 2017. The consideration of releasing Perkaban Number 15 Year 2017 is based on the existence of Law Number 11 of 2016 concerning Tax Amnesty (hereinafter referred to as the Tax Amnesty Law). In Article 15 of the Tax Amnesty Law, implicitly regulates the acquisition of nominees in the case of registration of transfer of land rights in the context of tax amnesty. The nominee is permitted by means of the correct taxpayer having the object of land rights together with the nominee to make a Statement by both parties before the notary stating that immovable property in the form of land and or building is the property of the taxpayer who conveys Statement letter, in the event that the property in question has not been able to submit a request for transfer of rights. The conditions are then given the opportunity to be implemented immediately at the latest on 31 December 2017 or at the end of 2017.

Article 1 letter a juncto b Perkaban Number 15 Year 2017 explains that the right land and or building belonging to the obligatory taxpayer who forgives tax on the land and or building but is still registered in the name of another person (which we call "nominee") must be transferred to on behalf of the Taxpayer in which the transfer of rights is carried out 
through the signing of a Statement by both parties, namely nominees and taxpayers who must be made before a Public Notary. The process is not completed by only making a Statement by both parties before the Notary and the parties only, but also must sign a Statement of Nominee Property Ownership and Treasure Recognition/ Nominee. After the files are complete and signed, the taxpayer who forgives the tax on the land rights object and the building can request and obtain a statement and exemption from the obligation to pay $\mathrm{PPh}$ (hereinafter referred to as SKB PPh) by attaching a tax amnesty statement and paying the money ransom other than the taxpayer must obtain a SKB PPh, the taxpayer is also required to pay off the payment of Land and Building Rights (BPHTB). Then it is also needed for the taxpayer to attach a tax amnesty statement, evidence of ransom payment, and evidence of payment of BPHTB payment. These three conditions can be attached to the application file for transfer of land rights, which can take the form of derivative documents or photocopies that have been legally validated by the authorities. Then new taxpayers can apply for the transfer of their land rights in the context of tax amnesty to the land office.

According to Article 2 paragraph (4) Perkaban Number 15 Year 2017, the land office conducts the name return process by mentioning the Land Book and the Land Rights Certificate pertaining to the clause as follows:

"A statement by both parties stating that the land and building are owned by taxpayers that made by the Public Notary: at on: date: year:

Number: in accordance with the provisions of article 15 of Law

Number 11 Year 2016 concerning Tax Amnesty juncto article 37 paragraph (2) of Government Regulation Number 24 Year 1997 concerning Land Registration. "

Looking at the principle of Perkaban Number 15 Year 2017 which confirms that the transfer of land rights in order of tax amnesty can be accommodated with a certificate of statement, clearly contrary to Article 37 paragraph (1) of the PP on Land Registration. In article 37 paragraph (1) PP Land registration confirms that:

"The transfer of land rights and ownership rights to apartment units through buying and selling, reciprocates, grants, the company income and other legal rights, except the transfer of rights through an auction, can only be registered, if proven by the certificate made by the authorized PPAT according to the provisions of the prevailing laws and regulations."

In the article which stipulated by Perkaban Number 15 Year 2017, it states that: "In accordance with the provisions of Article 15 of Law Number 11 Year 2016 concerning Tax Amnesty juncto with Article 37 paragraph (2) of Government Regulation Number 24 Year 1997 concerning Land Registration". The inclusion of Article 37 paragraph (2) states that: 
"In certain circumstances as determined by the Minister, the Head of the Land Office can register the transfer of title to the property rights that is carried out between the acquisition of Indonesian citizens as evidenced by a certificate not made by PPAT, but according to the Head of the Land Office the level of truth is considered sufficient to register the transfer related rights."

Perkaban Number 15 Year 2017 emphasizes orders for all land offices in the Regency or City to reverse names in order of Tax Amnesty. It can be said that the existence of Perkaban Number 15 Year 2017 actually explains the transfer of rights to land parcels carried out as such only in order of tax amnesty. It is very unfortunate if the Minister of Agrarian establishes a vital rule only in the form of Regulations of the Head Land Agency, since it is to form a Government Regulation in the field of land certainly requires a process that is not short, while the time promulgated by Article 15 paragraph (2) of the Law Tax Amnesty is only until $31^{\text {st }}$ December 2017 or the end of 2017. ${ }^{7}$ Therefore, the basis of turn back name in order of tax amnesty is only based on Perkaban Number 15 Year 2017. Although it is inappropriate for the researcher, at least there is still a legal basis for the National Land Agency in each Regency or City to normalize the interests of the community based on the law, especially the tax amnesty law.

According to Joko Widodo as the President of Indonesia, Law of Tax Amnesty is a solution in solving the taxation problems. The government built this strategy program with progressive socialization as an effort to achieve the goals in the Law of Tax Amnesty itself. The purpose of tax amnesty is to:

a. Accelerate the economic growth and restructure through the transfer of property, that can impact on the improvement of domestic liquidity, repairing the rupiah's exchange rate, reducing interest rates, and enhancement investment;

b. Encourage tax reform towards a more equitable taxation system and expansion of a more valid, comprehensive and integrated tax database;

c. Increasing tax revenues, which will be used to financing development."

There are several conveniences obtained by taxpayers when reporting land rights in the context of tax amnesty before December $31^{\text {st }}, 2017$, the first facility; for applicants who have been equipped with a notarial statement for land that has not been registered with the taxpayer of the Indonesian citizen whose land status has not been registered in accordance with the type of land rights according to the Law of Tax Amnesty, then the way to apply for

Santoso, Christian Adi.(2017).Perubahan Status Harta Bawaan dalam Rangka Pengampunan Pajak, Tesis pada Universitas Airlangga. 
recognition of rights and name changes can be done at once. Therefore, the process of recognizing the rights of nominees can be done together with the change of name on behalf the nominees to become the name of the taxpayer on the land book and certificate of land rights. Second, for an applicant whose number has passed away, but the land right has not been register, the taxpayer of the Indonesian citizen can apply for registration of recognition of rights and name changes at once. As result, the process of recognizing the rights in the name of the heirs and the process of changing name from the heir to the taxpayer can be recorded in the Land Book and certificate of land rights. The above facilities cannot be obtained by taxpayers if they have not registered the land rights until the deadline given which is after December $31^{\text {st }} 2017$. So the appeal given is to immediately register the land rights, even though the process of changing land rights has not been completed on December $31^{\text {st }}$, 2017, but the most important thing is that the registration application has been entered.

Related to the legal issues in this writing, inconsistencies that occur between Government Regulation Number 24 Year 1997 in order of Land Registration with Perkaban Number 15 Year 2017 in order of Registration of Transition of Land Rights in the Frame of Tax Amnesty, which should be a system of legislation arranged in a hierarchical where the lower should not conflict with higher regulations. If this happens, the principle of lex superior derogat legi inferior applies, which should exclude Perkaban Number 15 Year 2017 in order of Registration of Transfer of Land Rights in the Frame of Tax Amnesty as the legal low regulations.

As stated in Article 7 paragraph (1) of Law Number 12 Year 2011 concerning the Establishment of Legislation (hereinafter referred to as Law Number 12 Year 2011) confirms the type and hierarchy of legislation consists of:

1. The 1945 Constitution of the Republic of Indonesia;

2. Decree of the People's Consultative Assembly;

3. Law \& Government Regulation in Lieu of Law (PERPU);

4. Government Regulation;

5. Presidential Regulation;

6. Provincial Regional Regulations; and

7. District Regulations.

Although it was not categorized in the type and hierarchy of laws and regulations in Article 7 paragraph (1) Law Number 12 Year 2011, the position of Perkaban Number 15 Year 2017 is regulated in Article 8 paragraph (1) of Law Number 12 Year 2011 which confirms: 
"the type of legislation other than as referred to in Article 7 paragraph (1) includes regulations established by the People's Consultative Assembly, the People's Legislative Assembly, the Regional Representative Council, the Supreme Court, the Constitutional Court, the Supreme Audit Board, the Judicial Commission, Bank Indonesia, the Minister, Agency, Institution or Commission of the same level established by Law or Government on the orders of the Law, Provincial Regional People's Legislative Assembly, Governor, Regency Regional Representative Council”

Although the above provisions do not explicitly mention the type of legislation in the form of "Ministerial Regulations" but phrases "... the rules set by .... the minister ... " above reflects the existence of the Ministerial Regulation as one type of legislation. For the binding power regulated in Article 8 paragraph (2) which confirms that:

"the laws and regulations as referred to in paragraph (1) are acknowledged as having their existence and have binding legal force insofar as they are ordered by higher laws or are formed based on authority."

The regulation regarding the registration of land rights transfer in order of tax amnesty is based on Perkaban Number 15 Year 2017 juncto Circular Number 9/SE/X/2017. The ideals of the tax amnesty law itself are purely to increase state revenues, moreover the income from tax collection is the main income for the state treasury. However, with the birth of regulations regarding the registration of the transfer of rights to land in the frame of tax amnesty, it has an impact in the field of property.

\section{Validity of the Nominee Agreement in Legal Regulations in Indonesia}

The nominee agreement is not known at all in the legal system in Indonesia, especially in the Indonesian treaty law and there are no specific and explicit arrangements so that it can be said to contain a legal vacuum. It is stated in Article 26 of the LoGA that: "Every sale, reciprocates, grant, giving with will and other actions intended to directly or indirectly transfer ownership rights to foreigners, to a citizen who besides Indonesian citizenship has foreign citizenship or to a legal entity, unless the provisions of Article 21 paragraph (2) are null and void because the law and the land fall to the State, provided that the rights of the other party which continues to burden it and all payments received by the owner cannot be prosecuted.

Regarding nominee agreements used by foreigners to control and own property rights in Indonesia, the technicalities can occur by means of foreigners who actually buy a piece of property in Indonesia by using the name of an Indonesian citizen, which is a property that in fact is bought or paid for by the foreigner, but in the sale and purchase deed that carried out in 
front of the PPAT authorized by the Indonesian citizen, is the party of the buyer in the sale and purchase deed so that the object of the property is then registered to or on behalf of the Indonesian citizen. By registering to and on behalf of an Indonesian citizen on a certificate of ownership on land that is actually purchased or paid for by a foreigner, in order to obtain legal protection, between foreigners and Indonesian citizens an agreement is made in one or several agreements and even in a deed of statement stating that An Indonesian citizen is a person who only borrows his name in the proof of land ownership (certificate), while the real owner is the foreigner.

The process of making the deed as mentioned above constitutes legal smuggling and violates the law also violates the oath position and the oath of the official. Facing the request to make the deed as intended, the notary must expressly reject it because in addition of being a violation of the position, the deed that is made is not in accordance with the reality which in fact is detrimental to the other party. The certificate is one known as the Act of AntiDetermination, which is the contents of the deeds that are written not in accordance with the actual reality, for example the Deed of Buyer Declaration in the legal act on buying and selling land. In this case, the actual buyer is a person who is not allowed to have the certain land rights. ${ }^{8}$

Various efforts made by the parties, namely foreigners with Indonesian citizens or fellow citizens who have nominee agreements to overcome law for personal gain are categorized as legal smuggling proving the absence of good faith as stated in 1338 paragraph (3) of the Civil Code (the principle of freedom of contract). In addition, according to Article 1313 of the Civil Code the definition of an agreement is "... An act by which one person or more ties himself to one another or more." As an agreement, it must have undergone a testing mechanism. This test will determine that the agreement made is legal or not in the eyes of law. The article to test that an agreement is legally valid or not, is contained in Article 1320 of the Civil Code. ${ }^{9}$

Nominee agreements according to the legal terms of the contract must fulfill:

1. Requirements for the validity contract regulated in Article 1320 of the Civil Code; and $^{10}$

8 A.A. Andi Prajitno.(2010).Pengetahuan Praktis Tentang Apa Dan Siapa Notaris Di Indonesia, Surabaya: Putra Media Nusantara, p. 40.

9 Imelda Agung.(2017). Implikasi Akta Nominee Sebagai Dasar Permohonan Pengampunan Pajak, Jurnal Hukum Dan Perundangan Islam, Vol. 7 No. 2 Oktober 2017, p. 499.

10 Agus Yudha Hernoko.(2014). Hukum Perjanjian Asas Proporsionalitas Dalam Kontrak Komersial (Edisi Pertama) Cetakan ke-4, Jakarta: Prenadamedia Group, p.157. 
2. The legal terms of the contract are regulated outside Article 1320 (vide Articles 1335, 1337, 1339 and 1347 of the Civil Code).

In relation to tax amnesty, nominee agreements are permitted under Article 15 paragraph (2) letter b of the Tax Amnesty Law which confirms that:

"the signing of a statement by both parties in front of a notary stating that the Assets referred to in paragraph (1) letter a (immovable assets in the form of land and or buildings) are true of the Taxpayer who submits a Statement, in the event that the Assets cannot be submitted request for transfer of rights".

Back to the initial principle that the nominee agreement was prohibited and considered cancelled for the sake of law since the nominee agreement was a legal smuggling, if referring to article 15 paragraph (2) letter a vide Article 15 paragraph (1) letter a of the Tax Amnesty Law, apparently a nominee agreement in land law is permitted, but still with a note: only in the context of Tax Amnesty and the process of returning the title to the land title only. It is also supported if we remember the understanding in Article 1337 of the Civil Code, it is interpreted acontrario that in the case of prohibition has been stated in the law or legislation, is permissible. In other words, the nominee agreement in land law is permitted, but only in the context of tax amnesty and related to all subsequent processes of tax amnesty such as the return of the certificate name.

\section{CONCLUSION}

From the description above there are a number of things that can be concluded, First, The implication of the inconsistence of law in the registration of land rights transfer is that the nominee or the borrowing agreement is permitted as a basis for returning the name of the land rights certificate from the interested parties in the form of notarial deed namely the Deed of Statement, but it can only carried out in the frame of tax amnesty just as regulated in Perkaban Number 15 Year 2017 concerning Registration of Land Rights Transfer in the Frame of Tax Amnesty. Although in fact it deviates from the previous rules based on Article 37 of Government Regulation Number 24 Year 1997 concerning Land Registration, which involves the transfer of land rights and ownership rights to apartment units can only be done through buying and selling, reciprocates, grants, the company income and other legal acts of transfer of rights. Apparently, with the birth of regulations regarding the registration of the transfer of rights to land in order of tax amnesty, also created a legal impact, which is in the field of property. Second, The validity of the nominee agreement or loan name borrowing agreement 
in the legal regulations in Indonesia today is legally valid if the interpretation refers to Article 1337 of the Civil Code which interprets a contrario, that is, if the prohibited matter is set forth in law or legislation, then what is meant can be allowed. The provisions of the legislation referred to Article 15 paragraph (2) letter a vide Article 15 paragraph (1) letter a of the Law of Tax Amnesty and related to Perkaban 15 Year 2017 juncto Circular Number 9/SE/X/2017. Therefore, the nominee agreement in the form of the Deed of Declaration as referred in the regulation is permitted with a note: it can only be done in the context of Tax Amnesty and the process of returning the name of the land rights only.

\section{BIBILIOGRAPHY}

\section{Books}

A.A. Andi Prajitno.(2010). Pengetahuan Praktis Tentang Apa Dan Siapa Notaris Di Indonesia, Surabaya: Putra Media Nusantara.

Agus Yudha Hernoko.(2014). Hukum Perjanjian Asas Proporsionalitas Dalam Kontrak Komersial (Edisi Pertama, Jakarta: Prenadamedia Group.

Kusnu Goesniadhie.(2010). Harmonisasi Sistem Hukum, Mewujudkan Tata Pemerintahan yang Baik, Malang: Penerbit A3 dan Nasa Media.

Peter Mahmud Marzuki.(2008). Penelitian Hukum, Jakarta: Kencana Prenada Media. Urip Santoso.(2010). Pendaftaran dan Peralihan Hak atas Tanah, Jakarta: Kencana.

\section{Journals}

Christian Adi Santoso.(2017). Perubahan Status Harta Bawaan Dalam Rangka Pengampunan Pajak, Pascasarjana Magister Kenotariatan, Universitas Airlangga.

Cici Fajar Novita.(2014). Tinjauan Hukum Terhadap Jual Beli Tanah Tanpa Akta Ppat (Wilayah Kecamatan Tinombo), Jurnal Ilmu Hukum Legal Opinion, Edisi 3, Vol. 1, Tahun 2014.

Erlies Septiana Nurbani.(2018). Environmental Protection in International Humanitarian Law, UNRAM Law Review, Volume 2 Issue 1 2018, p.3.

Imelda Agung.(2017). Implikasi Akta Nominee Sebagai Dasar Permohonan Pengampunan Pajak, Jurnal Hukum Dan Perundangan Islam, Vol. 7 No. 2, Tahun 2017.

\section{Law and Regulations}

Undang-Undang Dasar Negara Republik Indonesia Tahun 1945

Kitab Undang-Undang Hukum Perdata

Undang-Undang Republik Indonesia Nomor 11 Tahun 2016 tentang Pengampunan Pajak 
Undang-Undang Republik Indonesia Nomor 5 Tahun 1960 tentang Peraturan Dasar PokokPokok Agraria

Peraturan Menteri Agraria dan Tata Ruang/Kepala Badan Pertanahan Nasional Republik Indonesia Nomor 15 Tahun 2017 tentang Pendaftaran Peralihan Hak Atas Tanah dalam Rangka Pengampunan Pajak

Peraturan Pemerintah Nomor 24 Tahun 1997 tentang Pendaftaran Tanah

Surat Edaran Nomor 9/SE/X/2017 Tentang Petunjuk Pelaksanaan Perkaban Nomor 15 Tahun 2017 